Article

\title{
Dissolution of Microcrystalline Cellulose in Phosphoric Acid- Molecular Changes and Kinetics
}

\author{
Junhua Zhang ${ }^{1}$, Jingqiang Zhang ${ }^{1}$, Lu Lin ${ }^{1, *}$, Tianming Chen ${ }^{1}$, Jun Zhang ${ }^{1}$, Shijie Liu ${ }^{2}$, \\ Zhenjiang $\mathrm{Li}^{3}$ and Pingkai Ouyang ${ }^{3}$
}

1 Department of Resources Science and Engineering, State Key Laboratory of Pulp and Paper Engineering, South China University of Technology, Guangzhou 510640, Guangdong Province, China

2 Department of Paper and Bioprocess Engineering, College of Environmental Science and Forestry, State University of New York, 1 Forestry Drive, Syracuse, NY 13210, USA

3 College of Medicine and Life Science, Nanjing University of Technology, Nanjing, 210009, China

* Author to whom correspondence should be addressed; E-Mail: 1clulin@scut.edu.cn.

Received: 4 November 2009; in revised form: 23 November 2009 / Accepted: 30 November 2009 / Published: 4 December 2009

\begin{abstract}
In this study, we aimed to dissolve microcrystalline cellulose (MCC) with phosphoric acid to obtain high-quality fermentable saccharides. MCC was directly dissolved in phosphoric acid (the concentration was 83\%) for 10 hours at temperatures of 30,50 , and $70{ }^{\circ} \mathrm{C}$. The structural changes of MCC were determined in detail with X-ray powder diffraction, solid-state cross-polarization magic angle spinning ${ }^{13} \mathrm{C}-\mathrm{NMR}$, and $\mathrm{X}$ ray photoelectron spectroscopy. The kinetics of MCC decrystallization during treatment with phosphoric acid was also compared at 30,50 , and $70{ }^{\circ} \mathrm{C}$. With the assumption of first order kinetics, the Arrhenius parameters of $K, A_{0}$ and $E_{a}$ were calculated. The rate constants of decrystallization reaction $(K)$ were $0.06,0.17$, and $0.12 \mathrm{~h}^{-1}$ respectively. The pre-exponential factor $\left(A_{0}\right)$ was $1.2 \times 10^{6} \mathrm{~h}^{-1}$, and the activation energy $\left(E_{a}\right)$ was $42.4 \mathrm{k} \mathrm{J} / \mathrm{mol}$.
\end{abstract}

Keywords: kinetic; MCC; phosphoric acid; decrystallization; structural change 


\section{Introduction}

It is well known that petrochemical resources are diminishing and alternatives must be found to produce the energy and chemical materials required by society. In order to meet the growing demand for energy, microcrystalline cellulose (MCC) can serve as a sustainable source of renewable fuels and chemicals.

Cellulose is the most abundant renewable polymer which can be derived from plant biomass, and its efficacious utilization would represent a significant source of sustainable energy. However, due to its compact crystalline structure which is formed mainly by inter- and intra-molecular hydrogen bonds, cellulose is usually difficult to hydrolyze into fermentable sugars [1]. Therefore, this highly-ordered cellulose structure is very difficult to dissolve with chemicals or bio-enzymes [2-6], and this rigidity poses a challenge to the efficacious utilization of cellulose. Thus, a better method for the decrystallization of lignocellulose is urgently needed for improving its utilization efficiency and producing simple sugars for fermentation to produce ethanol fuel and other bio-based products [7].

The traditional decrystallization pathways for MCC include using physical [8-11] or chemical methods. The chemical methods include the use of ionic liquids [12,13], NaOH/urea [14] or phosphoric acid [15-18]. In the chemical method, phosphoric acid has been the most popular solvent for dissolution of crystalline cellulose for over 80 years due to its non-corrosive and nontoxic properties, its safe use and low cost compared to other inorganic mineral acids [19]. Walseth [20] first developed a procedure for producing high-reactivity cellulose suitable for cellulose activity studies by swelling air-dried cellulose in $85 \%$ phosphoric acid. After dissolving crystalline cellulose, the solubilized precursors can be formed, which can subsequently be catalytically hydrolyzed, using either biological or synthetic catalysts. Cellulose dissolution in phosphoric acid involves two main processes:

(1) An esterification reaction between hydroxyl groups of cellulose and phosphoric acid to form cellulose phosphate:

$$
\mathrm{H}_{3} \mathrm{PO}_{4}+\mathrm{HO} \text {-cellulose } \longleftrightarrow \text { cellulose- } \mathrm{O}-\mathrm{PO}_{3} \mathrm{H}_{2}
$$

and (2) a competition of hydrogen-bond formation between hydroxyl groups of cellulose chains and hydrogen-bond formation between one hydroxyl group of a cellulose chain and a water molecule or with a hydrogen ion Meanwhile, another by-reaction, acid hydrolysis of $\beta$-glucosidic bonds of cellulose will take place. However, such acid hydrolysis can be minimized by decreasing the dissolution temperature [21]. During the regeneration process by water, cellulose phosphate reversibly can be converted back to free phosphoric acid and amorphous cellulose without any significant substitution or recrystallization.

In this study, MCC was dissolved in phosphoric acid (83\%) at different temperatures. The structural changes of cellulose were analyzed by X-ray powder diffraction (XRD), Solid-State CrossPolarization Magic Angle Spinning (CP/MAS) ${ }^{13} \mathrm{C}-\mathrm{NMR}$ spectroscopy and X-ray photoelectron spectroscopy (XPS). Our aim was to reduce the crystallinity of MCC cellulose by treatment with phosphoric acid in order to obtain under mild hydrolysis conditions high-quality fermentable saccharides which can be converted into bio-ethanol or bio-based chemicals. 


\section{Result and Discussion}

\subsection{The $\chi_{c}$ change of MCC analyzed by XRD}

Figure 1 shows the effect of temperature on the decrystallization of MCC with phosphoric acid at 2, 4 , and $6 \mathrm{~h}$. At $30{ }^{\circ} \mathrm{C}$, the $\chi_{c}$ numbers were $79.4 \%, 72.6 \%$, and $63.1 \%$, respectively, for 2,4 , and $6 \mathrm{~h}$. At $50{ }^{\circ} \mathrm{C}$, the $\chi_{c}$ numbers were decreased to $70.6 \%, 57.3 \%$, and $39.1 \%$, respectively, for 2,4 , and $6 \mathrm{~h}$, then to $63.8 \%, 50.6 \%$, and $43.4 \%$ at $70{ }^{\circ} \mathrm{C}$. At temperatures of $30{ }^{\circ} \mathrm{C}$ and $50{ }^{\circ} \mathrm{C}$, the degrees of crystallinity of the cellulose decreased with increasing reaction time, which is in agreement with the reports of Ekenstam et al. [22] and Danilove et al. [23]. However, at the higher temperature of $70{ }^{\circ} \mathrm{C}$, with a longer reaction time (for example, $6 \mathrm{~h}$ in this study), the decrystallization effect was reduced, which is undesirable because cellulose of low crystallinity is easier to hydrolyze.

Figure 1. Effect of temperature on decrystallization of MCC with phosphoric acid.

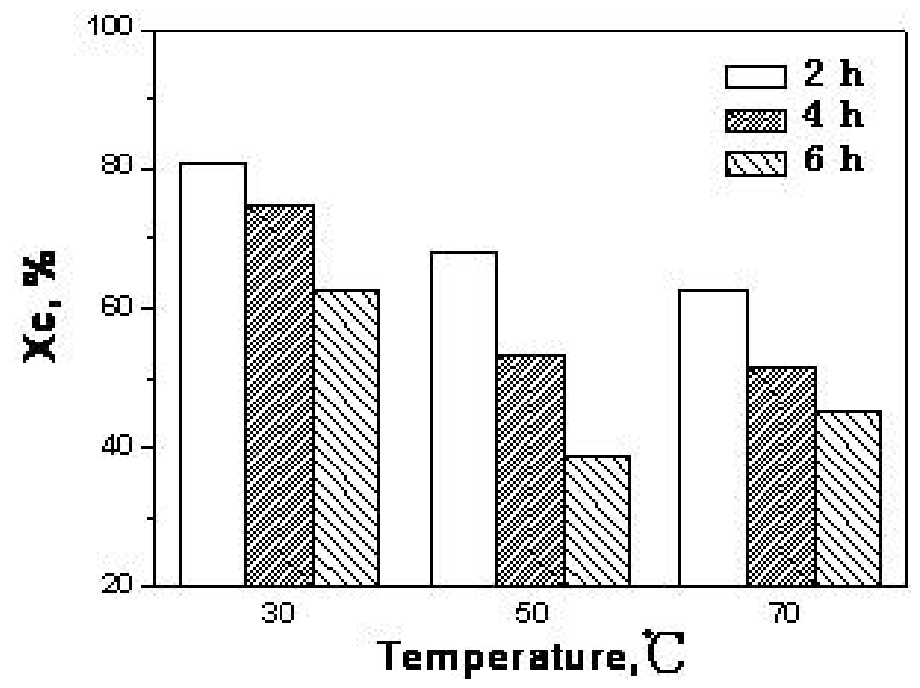

Figure 2 shows the XRD patterns of MCC treated with phosphoric acid at $50^{\circ} \mathrm{C}$ at different times. The MCC spectrum showed characteristic peaks of cellulose I at the $2 \theta$ of $14.7^{\circ}, 16.5^{\circ}, 22.8^{\circ}, 34.5^{\circ}$, and cellulose II at the $2 \theta$ of $12^{\circ}, 20^{\circ}$, respectively. With the dissolution of cellulose, the crystal peaks decreased greatly, and the degree of crystallinity also decreased from $92.2 \%$ to $39.1 \%$. Thus, the regenerated cellulose prepared with phosphoric acid had low crystallinity and the reaction with phosphoric acid had markedly destroyed the crystal regions of the MCC. The relative content of amorphous regions increased. It can also be seen that the breadth of the characteristic cellulose II $2 \theta$ peak at $20^{\circ}$ increased when MCC treated with phosphoric acid for 2 hours, and then, decreased gradually. Moreover, this characteristic $2 \theta$ peak at $12^{\circ}$ begun to appear with the treatment of phosphoric acid, and then disappeared at $6 \mathrm{~h}$, all of these indicating that the cellulose II was a transition form during the course of the transformation of cellulose I into amorphous cellulose. 
Figure 2. X-ray diffraction patterns of MCC samples with phosphoric acid at $50{ }^{\circ} \mathrm{C}$. The characteristic peaks of cellulose I were: $2 \theta=14.7^{\circ}, 16.5^{\circ}, 22.8^{\circ}$, and $34.5^{\circ}$; The characteristic peaks of cellulose II were: $2 \theta=12^{\circ}$ and $20^{\circ}$.
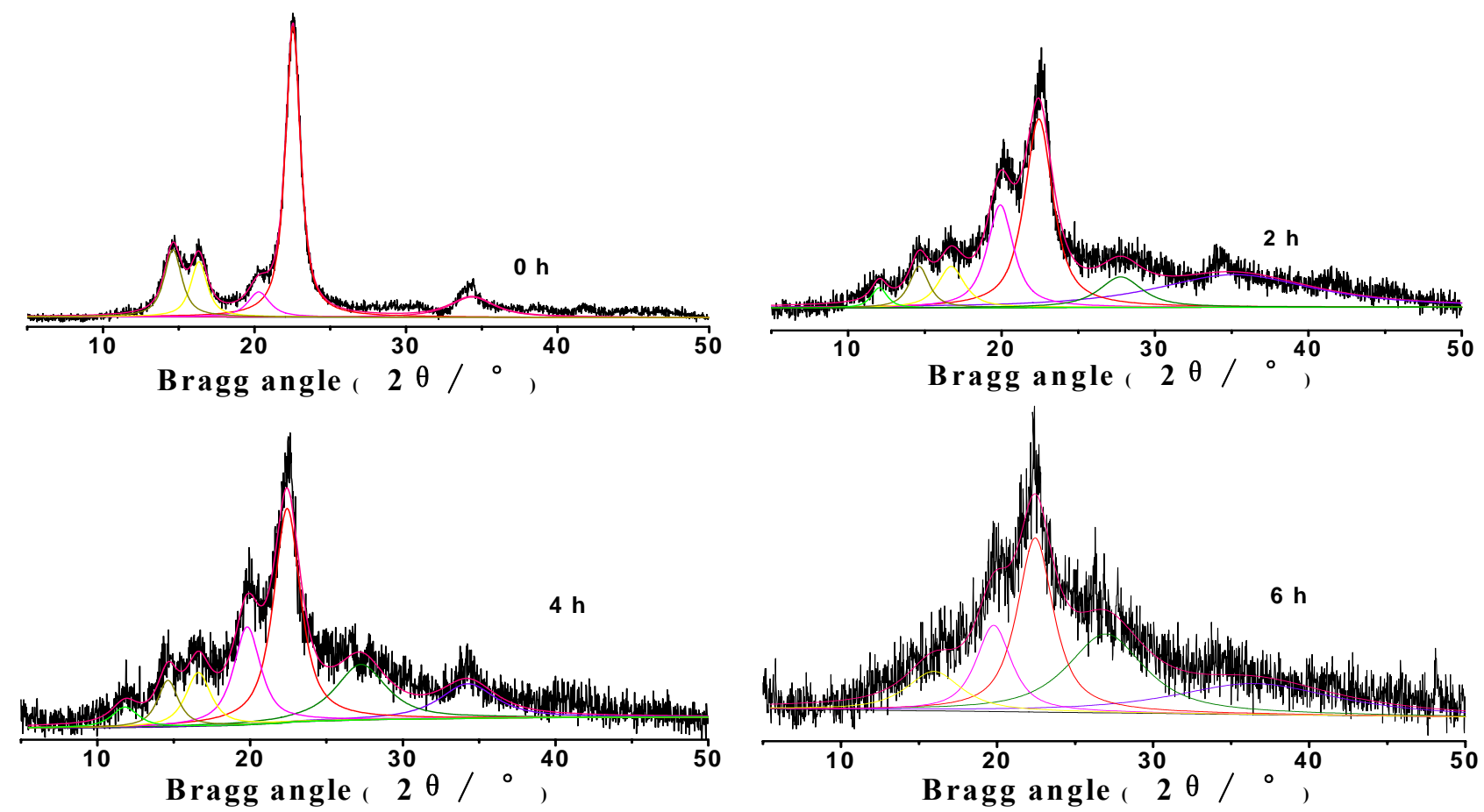

\section{2. $C P / M A S{ }^{13} C-N M R$ Analysis}

The chemical shifts detected with $\mathrm{CP} / \mathrm{MAS}{ }^{13} \mathrm{C}$ solid-state NMR spectra of the carbons $\left(\mathrm{C}_{1}-\mathrm{C}_{6}\right)$ in MCC are shown in Table 1.

Table 1. Resonance assignments for the $\mathrm{CP} / \mathrm{MAS}{ }^{13} \mathrm{C}$ NMR spectra of cellulose and cellulose treated using phosphoric acid.

\begin{tabular}{|c|c|c|c|}
\hline \multirow{2}{*}{ Carbon atom } & \multicolumn{3}{|c|}{ Chemical shift ( ppm, $\delta$ ) } \\
\hline & $\mathrm{Xc}=92.23 \%$ & $\mathrm{Xc}=\mathbf{7 1 . 7 3 \%}$ & $\mathrm{Xc}=67.47 \%$ \\
\hline $\mathrm{C}_{1}$ & $\begin{array}{c}106.7,106 \\
105\end{array}$ & $\begin{array}{cc}106.8, & 106.2, \\
3 & 105 .\end{array}$ & $\begin{array}{cc}106.8, & 105.9, \\
3 & 105 .\end{array}$ \\
\hline Crystalline $\mathrm{C}_{4}$ & 89.9 & 89.9 & 90 \\
\hline Amorphous $\mathrm{C}_{4}$ & 84.6 & 83.7 & 83.6 \\
\hline $\mathrm{C}_{2}, \mathrm{C}_{3}, \mathrm{C}_{5}$ & $\begin{array}{c}75.8,73.4 \\
72.3\end{array}$ & $76,75.5,73.7$ & $76.1,73.7,72.6$ \\
\hline Crystalline $\mathrm{C}_{6}$ & 65.9 & 66.5 & 66.1 \\
\hline Amorphous $\mathrm{C}_{6}$ & 63.5 & 64.8 & 63.3 \\
\hline
\end{tabular}

Figure 3 shows that the cellulose $\mathrm{C}_{1}$ of $\mathrm{MCC}$ has three characteristic peaks at $105 \mathrm{ppm}$. The cellulose $\mathrm{C}_{4}$ has two characteristic peaks at $80 \sim 92 \mathrm{ppm}$. The cellulose $\mathrm{C}_{6}$ has two characteristic peaks at 58 69 ppm. MCC has three characteristic peaks at 72 78 ppm which are the characteristic peaks of the cellulose $\mathrm{C}_{2}, \mathrm{C}_{3}$ and $\mathrm{C}_{5}$, but there is disagreement about the assignment of the signals of these 
carbons. Teeäär et al. [24] thought that the signals at 76.8 and $76.0 \mathrm{ppm}$ could be ascribed to the cellulose $\mathrm{C}_{2}$, and the one at $73.0 \mathrm{ppm}$ was attributable to cellulose $\mathrm{C}_{5}$, and the intensity of $74.2 \mathrm{ppm}$ was assigned to the cellulose $\mathrm{C}_{3}$, but Kono et al. [25] deemed that the signals at 76.8 and $76.0 \mathrm{ppm}$ were from the cellulose $\mathrm{C}_{3}$ and Bardet et al. [26] considered that the $76.0 \mathrm{ppm}$ signal corresponded to cellulose $C_{2}$, and the peak at 74 ppm was from the cellulose $C_{3}$ and $C_{5}$. For all of these reasons, we did not discuss the characteristic peaks of $\mathrm{C}_{2}, \mathrm{C}_{3}$ and $\mathrm{C}_{5}$ in this paper.

Figure 3. CP/MAS ${ }^{13} \mathrm{C}-\mathrm{NMR}$ spectra of $\mathrm{MCC}$. The labeled peaks (labels are above the MCC trace) represent the intensities of carbons 1-6 $\left(\mathrm{C}_{1}-\mathrm{C}_{6}\right)$.

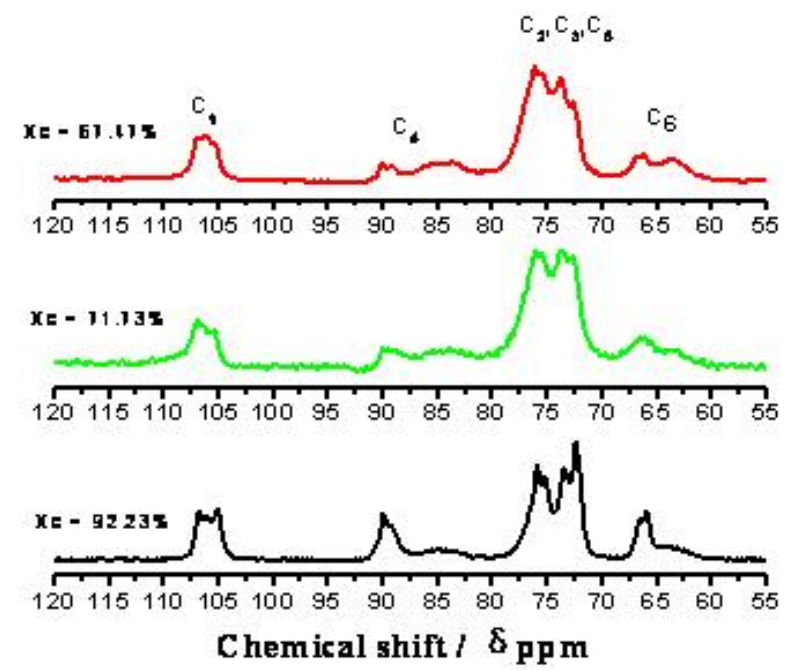

In the spectra of $\mathrm{CP} / \mathrm{MAS}{ }^{13} \mathrm{C}$ solid-state $\mathrm{NMR}$, the most valuable peak was $\mathrm{C}_{4}$. It was considered that the peak at 80 86 ppm was from the amorphous zone, and the peak 86 92 ppm was the crystalline and para-crystalline zones [27,28]. Figure 4 and Table 2 shows the distinct steps of $\mathrm{C}_{4}$ in the conversion from the crystalline zone to an amorphous zone with phosphoric acid treatment [29-31].

Figure 4. Results of fitting the $\mathrm{C}_{4}$ region of $\mathrm{CP} / \mathrm{MAS}{ }^{13} \mathrm{C}-\mathrm{NMR}$ spectra from MCC with different degrees of crystalline structure: The proportions of cellulose Ia, I(a $+\beta)$, paracrystalline, and I $\beta$ are identified in the first peaks; the proportions of amorphous cellulose and fibril surfaces are identified in the second peaks.

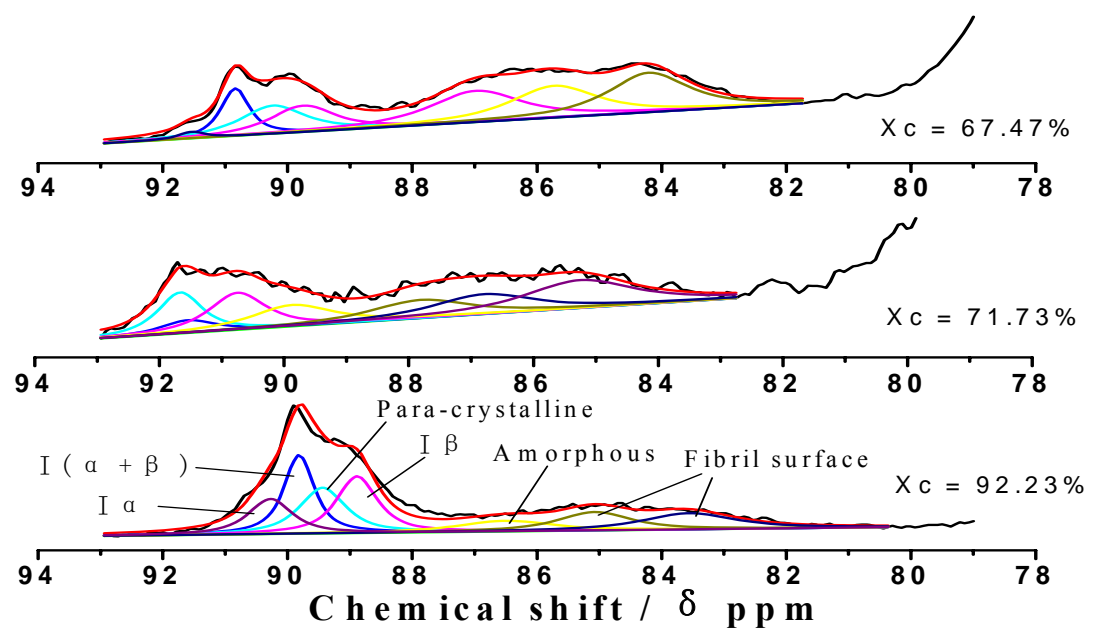


Table 2. Assignments and Intensity of Non-linear Least-squares fitting of the $\mathrm{C}_{4}$ region of the $\mathrm{CP} / \mathrm{MAS}{ }^{13} \mathrm{C}-\mathrm{NMR}$ Spectra from MCC with different degrees of crystallinity.

\begin{tabular}{|c|c|c|c|}
\hline $\mathrm{Xc}, \%$ & $\begin{array}{c}\text { Chemical shift } \\
\text { Assignments }\end{array}$ & $\begin{array}{c}\text { Chemical shift } \\
\text { ppm }\end{array}$ & $\begin{array}{c}\text { Intensity } \\
\%\end{array}$ \\
\hline \multirow{7}{*}{92.23} & $\mathrm{I} \alpha$ & 90.3 & 12.6 \\
\hline & $\mathrm{I}(\alpha+\beta)$ & 89.8 & 19.6 \\
\hline & Para-crystalline & 89.4 & 17.3 \\
\hline & $\mathrm{I} \beta$ & 88.9 & 19.0 \\
\hline & Amorphous & 86.5 & 8.2 \\
\hline & Fibril surface & 85.1 & 11.1 \\
\hline & Fibril surface & 83.6 & 12.2 \\
\hline \multirow{7}{*}{71.73} & $\mathrm{I} \alpha$ & 89.7 & 5.2 \\
\hline & $\mathrm{I}(\alpha+\beta)$ & 89.9 & 13.8 \\
\hline & Para-crystalline & 88.9 & 16.0 \\
\hline & $\mathrm{I} \beta$ & 88.1 & 13.1 \\
\hline & Amorphous & 86 & 13.5 \\
\hline & Fibril surface & 85 & 15.3 \\
\hline & Fibril surface & 83.5 & 23.1 \\
\hline \multirow{7}{*}{67.47} & $\mathrm{I} \alpha$ & 90.7 & 1.3 \\
\hline & $\mathrm{I}(\alpha+\beta)$ & 90.1 & 9.8 \\
\hline & Para-crystalline & 89.4 & 13.3 \\
\hline & $\mathrm{I} \beta$ & 89 & 12.3 \\
\hline & Amorphous & 86.2 & 20.6 \\
\hline & Fibril surface & 84.9 & 19.9 \\
\hline & Fibril surface & 83.4 & 22.8 \\
\hline
\end{tabular}

With the decrease of the degree of crystallinity, the percentages of $\mathrm{I} \alpha, \mathrm{I}(\alpha+\beta)$, para-crystaline, and I $\beta$ forms of crystalline cellulose $\mathrm{C}_{4}$ are greatly reduced from $68.5 \%$ to $48.1 \%$ and to $36.7 \%$, respectively. The corresponding amorphous cellulose $\mathrm{C}_{4}$ increased from $31.5 \%$ to $51.9 \%$ and to $63.3 \%$, respectively.

Figure 5 and Table 3 shows the distinct steps of $\mathrm{C}_{6}$ in the conversion from the crystalline zone to an amorphous zone with phosphoric acid treatment. With the decreasing of degree of crystallinity, the percentages of $\mathrm{I} \alpha, \mathrm{I}(\alpha+\beta)$, para-crystaline, and $\mathrm{I} \beta$ forms of crystalline cellulose $\mathrm{C}_{6}$ are greatly reduced from $59.4 \%$ to $35.4 \%$ and to $32.4 \%$, respectively. The corresponding amorphous cellulose $\mathrm{C}_{6}$ increased from $40.6 \%$ to $64.6 \%$ and to $67.6 \%$, respectively. All these results indicated that the compact network structure of cellulose became looser with the rupture of hydrogen bonds as a result of the step by step decrystallization process induced by phosphoric acid. 
Figure 5. Results of fitting the $\mathrm{C}_{6}$ region of CP/MAS ${ }^{13} \mathrm{C}-\mathrm{NMR}$ spectra from MCC with different degrees of crystalline structure: The proportions of crystalline cellulose are identified in the first peaks; the proportions of amorphous cellulose are identified in the second peaks.

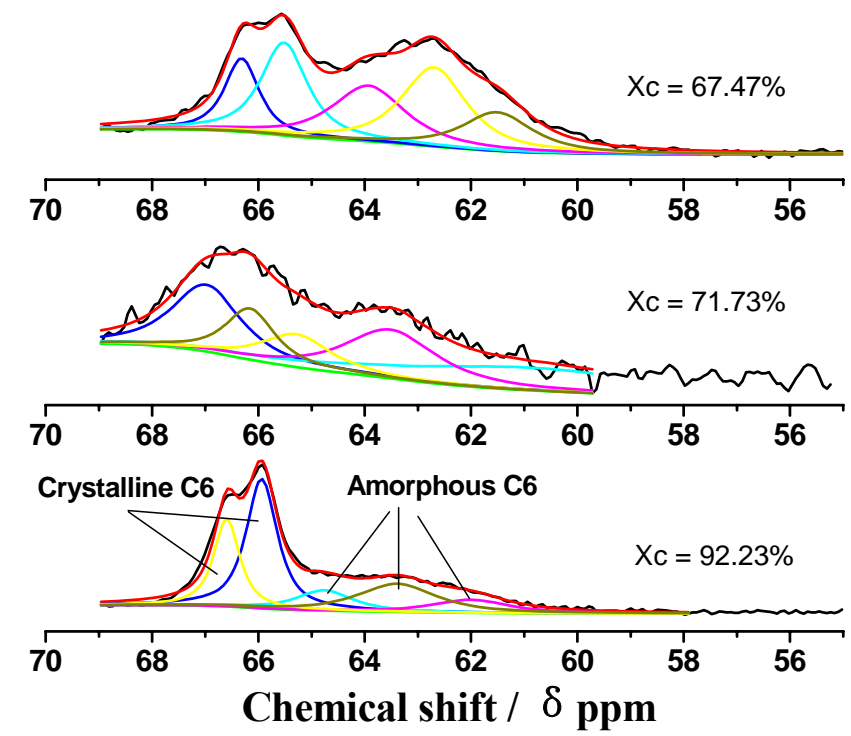

Table 3. Assignments and Intensity of Non-linear Least-squares fitting of the $\mathrm{C}_{6}$ region of the CP/MAS ${ }^{13} \mathrm{C}$-NMR Spectra from MCC with different crystalline degree.

\begin{tabular}{cccc}
\hline \multirow{2}{*}{$\mathbf{X c}, \boldsymbol{\%}$} & $\begin{array}{c}\text { Chemical shift } \\
\text { Assignments }\end{array}$ & Crystalline $\mathbf{C}_{\mathbf{6}}$ & Amorphous $\mathbf{C}_{\mathbf{6}}$ \\
\hline \multirow{3}{*}{92.23} & Chemical shift (ppm) & $66.6,65.9$ & $64.8,63.4,62$ \\
& Intensity (\%) & $21.4,38$ & $10.8,20.4,9.4$ \\
& Total Intensity (\%) & 59.4 & 40.6 \\
\hline \multirow{3}{*}{71.73} & Chemical shift (ppm) & $66.8,65.9$ & $65.1,63.3,60.7$ \\
& Intensity (\%) & $22.7,12.7$ & $11.3,22.3,30.9$ \\
& Total Intensity (\%) & 35.4 & 64.6 \\
\hline \multirow{2}{*}{67.47} & Chemical shift (ppm) & $66.9,66.1$ & $64.5,63.3,62.1$ \\
& Intensity (\%) & $13.4,18.9$ & $23.7,29.3,14.6$ \\
& Total Intensity (\%) & 32.4 & 67.6 \\
\hline
\end{tabular}

\subsection{XPS analysis of MCC treated with phosphoric acid}

Figure 6 shows the XPS wide scan spectra of MCC. There are only two significant peaks: $\mathrm{O}_{1 \mathrm{~s}}$ and $\mathrm{C}_{1 \mathrm{~S}}$, exist in the untreated MCC (sample 1). However, after the decrystallization treatment, a weak peak could be detected at around $401 \mathrm{eV}$, which is the signal for $\mathrm{N}_{1 \mathrm{~S}}$ (the spectra of sample 2 and 3 ). This result implies that a very small amount of nitrogen existed on the surface of cellulose, even after careful washing. In the crystalline structure of cellulose, there are two kinds of hydrogen bonds: (1) O$\mathrm{H} \cdots \mathrm{O}$ and (2) $\mathrm{C}-\mathrm{H} \cdots \mathrm{O}$, which are closely related to the oxygen and carbon atoms in the cellulose macromolecule. 
Figure 6. XPS wide scan patterns of MCC with different crystalline degree shows the $\mathrm{O}_{1 \mathrm{~S}}$, $\mathrm{N}_{1 \mathrm{~S}}$, and $\mathrm{C}_{1 \mathrm{~S}}$ binding energies: Sample $1(\mathrm{Xc}=92.23 \%)$; Sample $2(\mathrm{Xc}=71.73 \%)$; Sample $3(\mathrm{Xc}=67.47 \%)$.

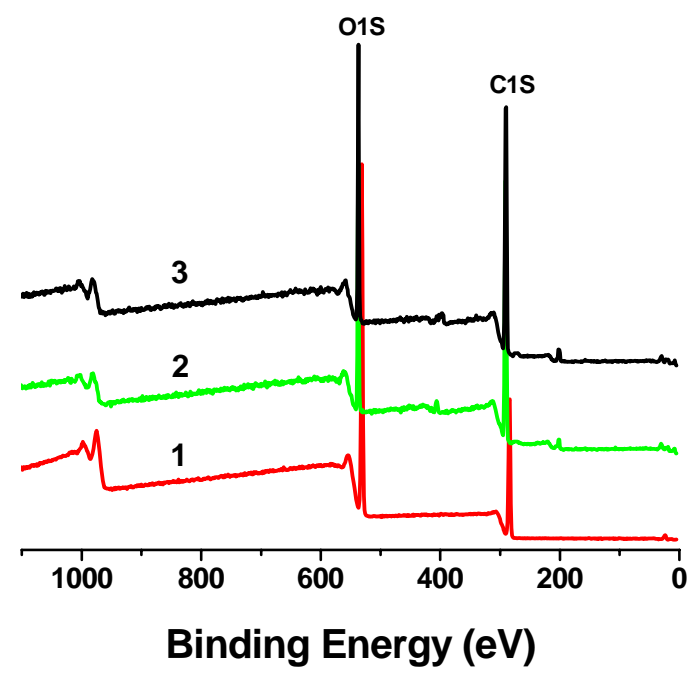

Figure 7. $\mathrm{C}_{1 \mathrm{~s}}$ XPS patterns of MCC with different crystalline degree show the three phases of $\mathrm{C}_{1 \mathrm{~S}}$ : Sample $1(\mathrm{Xc}=92.23 \%)$; Sample $2(\mathrm{Xc}=71.73 \%)$; Sample $3(\mathrm{Xc}=67.47 \%)$.

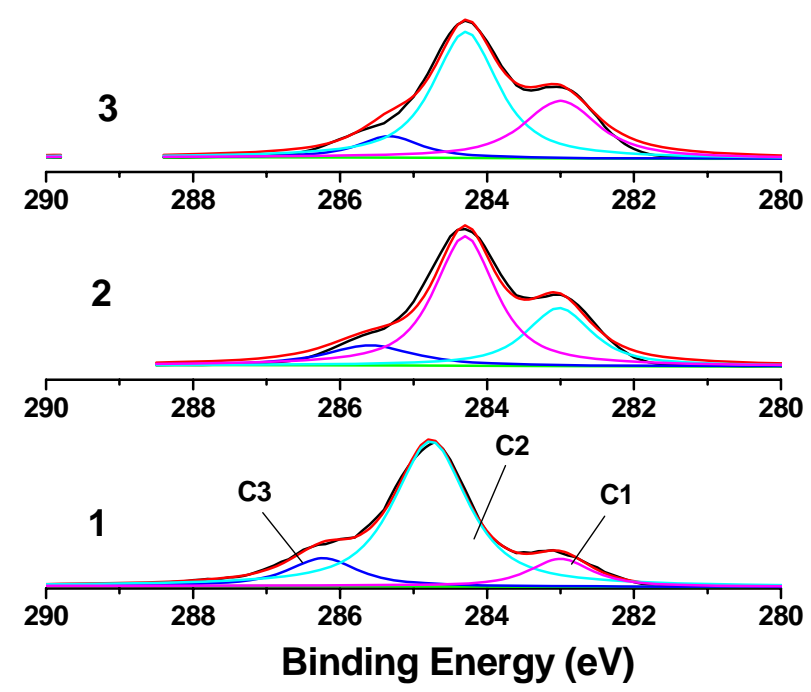

In the XPS spectra of cellulose, $\mathrm{C}_{1 \mathrm{~S}}$ can be divided into three phases [32]: (1) $\mathrm{C}_{1}$ is the carbon atom linking only with a carbon or hydrogen atom at low binding energy (at about $283.00 \mathrm{eV}$ ), forming the chemical bond $\mathrm{C}-\mathrm{C}$ or $\mathrm{C}-\mathrm{H}$; (2) $\mathrm{C}_{2}$ is the carbon atom linking with one oxygen atom not from a carbonyl group, but from a hydroxyl $(-\mathrm{OH})$ group; binding energy is about $284.77 \mathrm{eV}$, forming the chemical bond $\mathrm{C}-\mathrm{OH}$; (3) $\mathrm{C}_{3}$ is the carbon atom linking with two oxygen atoms not from a carbonyl group, or with one oxygen atom of a carbonyl group, forming the chemical bond $\mathrm{O}-\mathrm{C}-\mathrm{O}$ or $\mathrm{C}=\mathrm{O}$, with a binding energy of about $286.23 \mathrm{eV}$. Figure 7 shows the $\mathrm{C}_{1 \mathrm{~S}}$ XPS spectrum of MCC samples of different degrees of crystallinity. The $\mathrm{C}_{1}(\mathrm{C}-\mathrm{C} / \mathrm{C}-\mathrm{H})$ contents are $14.5 \%, 28.2 \%$, and $33.1 \%$, respectively, for sample 1,2 , and 3 . The $\mathrm{C}_{2}(\mathrm{C}-\mathrm{OH})$ are $68.1 \%, 58.9 \%$, and $56.3 \%$, respectively, and for $\mathrm{C}_{3}(\mathrm{O}-\mathrm{C}-\mathrm{O})$ are $16.4 \%, 12.9 \%$, and $10.6 \%$, respectively. These data have been calculated from the 
corresponding relative peak areas and the $\mathrm{C}_{1}(\mathrm{C}-\mathrm{C} / \mathrm{C}-\mathrm{H})$ and $\mathrm{C}_{2}(\mathrm{C}-\mathrm{OH})$ peaks are the predominant ones. It is well known that there are three active hydroxyls $(-\mathrm{OH})$ on the No. 2, 3, 6 carbons of the $\beta$-Dglucopyranose unit of cellulose, forming intramolecular hydrogen bonds $\mathrm{C}_{3}-\mathrm{OH} \ldots \mathrm{O}_{5}, \mathrm{C}_{2}-\mathrm{OH} \ldots \mathrm{O}_{6}$ and the intermolecular hydrogen bond $\mathrm{C}_{6}-\mathrm{OH} \ldots \mathrm{O}_{3}$. This indicates that a hydroxyl $(-\mathrm{OH})$ domain exists in the inner cellulose structure and the units of lignin and hemicellulose are mainly $\mathrm{C}-\mathrm{C}$ and $\mathrm{C}-\mathrm{H}$ units. After treatment with phosphoric acid, the original compact crystalline structure of MCC became looser, exposing more and more glucose rings. In the $\mathrm{C}_{1 \mathrm{~S}}$ XPS spectra of untreated and treated MCC, it is can thus be seen that the relative peak area of $\mathrm{C}_{2}(\mathrm{C}-\mathrm{OH})$ decreased extensively (from $68.1 \%$ to $58.9 \%$ and to $56.3 \%$ ), indicating that the hydrogen bond was destroyed after the phosphoric acid treatment. Moreover, it can be seen (Table 4) that the relative peak area of $\mathrm{C}_{1}(\mathrm{C}-\mathrm{C} / \mathrm{C}-\mathrm{H})$ increased from $14.5 \%$ to $28.2 \%$ and to $33.1 \%$ with the decreasing of crystallinity, indicating that the hydrogen bond's binding ability for cellulose chain was suppressed after the treatment of phosphoric acid, and so the intensity of C-C/C-H was increased.

Table 4. The $\mathrm{C}_{1 \mathrm{~s}}$ XPS datum of MCC with different crystalline degree.

\begin{tabular}{cccccccccc}
\hline \multirow{2}{*}{$\begin{array}{c}\mathbf{X c} \\
\mathbf{\%}\end{array}$} & \multicolumn{3}{c}{$\begin{array}{c}\text { Peak position } \\
\boldsymbol{E B} / \mathbf{e V}\end{array}$} & \multicolumn{4}{c}{$\begin{array}{c}\text { Separation } \\
\boldsymbol{E B} / \mathbf{e V}\end{array}$} & \multicolumn{3}{c}{$\begin{array}{c}\text { Area } \\
\boldsymbol{A} / \boldsymbol{\%}\end{array}$} \\
\cline { 2 - 11 } & $\mathbf{C}_{\mathbf{1}}$ & $\mathbf{C}_{\mathbf{2}}$ & $\mathbf{C}_{\mathbf{3}}$ & $\mathbf{C}_{\mathbf{1}}$ & $\mathbf{C}_{\boldsymbol{2}}$ & $\mathbf{C}_{\mathbf{3}}$ & $\mathbf{C}_{\mathbf{1}}$ & $\mathbf{C}_{\mathbf{2}}$ & $\mathbf{C}_{\boldsymbol{3}}$ \\
\hline 92.23 & 283.00 & 284.77 & 286.23 & 0.00 & 1.77 & 3.23 & 14.5 & 68.1 & 16.4 \\
71.73 & 283.42 & 284.70 & 286.00 & 0.00 & 1.28 & 2.58 & 28.2 & 58.9 & 12.9 \\
67.47 & 283.40 & 284.66 & 285.73 & 0.00 & 1.26 & 2.33 & 33.1 & 56.3 & 10.6 \\
\hline
\end{tabular}

\subsection{The kinetic analysis of cellulose dissolution in phosphoric acid}

The kinetics for MCC decrystallization was examined in a water bath. Figure 8 shows an example of the time-dependent decrystallization curves at three different temperatures over $10 \mathrm{~h}$. The relative content of crystalline cellulose (Cs) in MCC decreased with time at all temperatures. At a temperature of $30{ }^{\circ} \mathrm{C}$, the contents of crystalline cellulose reduced slowly and gradually leveled off at the end of reaction. The results indicated that the higher temperatures increased the rate of MCC decrystallization and resulted in lower proportions of crystalline cellulose.

Figure 8. The relative crystalline cellulose content $(\mathrm{Cs}$, which was determined by the intensity of 002 peak of sample's XRD) in MCC with phosphoric acid.

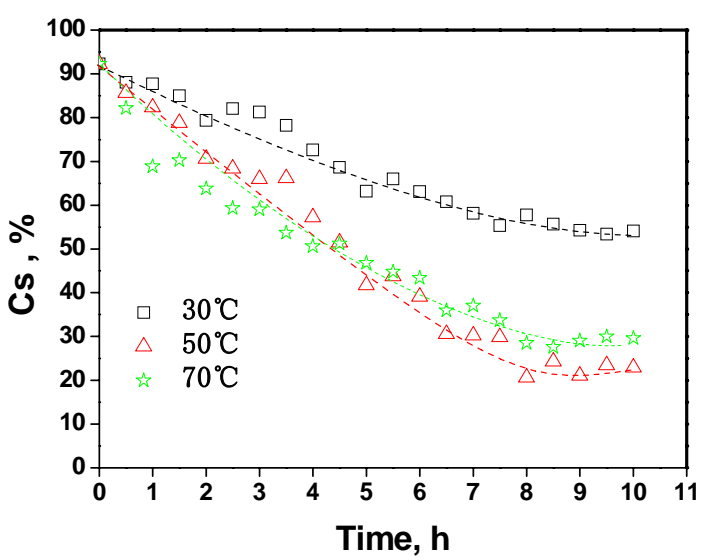


The kinetics for wheat straw decrystallization were derived under the assumption that the following conditions were met: (i) at reaction temperatures under $50{ }^{\circ} \mathrm{C}$, the phosphoric acid did not lead to the decomposition of cellulose, hemicelluloses, and lignin in wheat straw, (ii) phosphoric acid only reacted with crystalline structures, (iii) the quality of phosphoric acid did not change during the reaction, and (iv) the crystallinity index measured by XRD represented the relative content of crystalline cellulose in MCC. We formulated an equation that provided a good description of the kinetics of the decrystallization behavior of phosphoric acid on MCC. The kinetic model for the decrystallization process is:

$$
C s \stackrel{k}{\longrightarrow} A s
$$

where $C s$ is the crystalline cellulose in MCC, $A s$ is the amorphous cellulose in MCC, and $K$ is the decrystallization rate of MCC treated with phosphoric acid.

Based on this kinetic model, the kinetics for MCC decrystallization over the reaction time can be expressed with the following equation:

$$
d T t s / d t=k(1-T t s)
$$

where $T t s$ is the the fraction of crystalline cellulose in MCC.

From equation (2), the following equation was derived:

$$
\ln \frac{1}{1-T t s}=k t
$$

The conversion rates $(k)$ of crystalline cellulose to amorphous cellulose at 30,50 , and $70{ }^{\circ} \mathrm{C}$ were obtained for equation (3) from the plots of the decrystallization experiments (Figure 9).

Figure 9. Transformation rate mathematical modeling of crystalline cellulose in MCC.

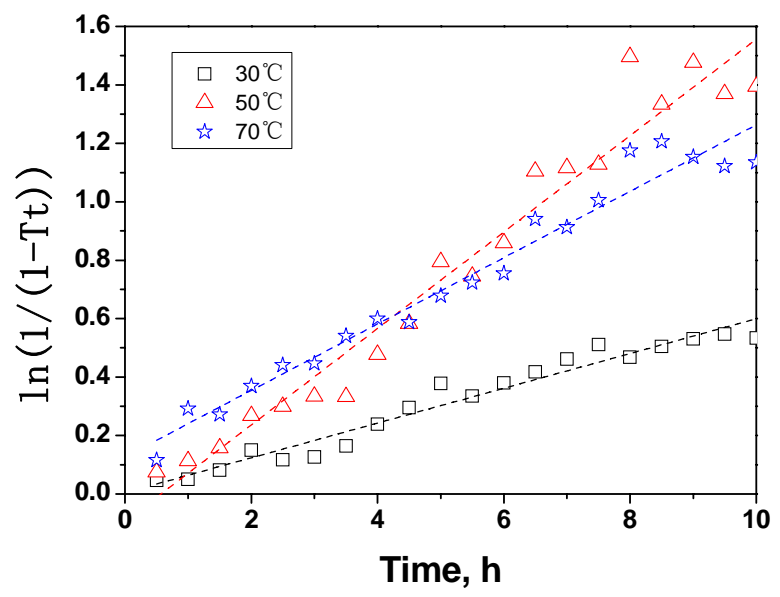

The rate constants of decrystallization reaction at 30,50 , and $70{ }^{\circ} \mathrm{C}$ were $0.06,0.17$, and $0.12 \mathrm{~h}^{-1}$, respectively. The rate constants at $50{ }^{\circ} \mathrm{C}$ and $70{ }^{\circ} \mathrm{C}$ were much higher than that of $30^{\circ} \mathrm{C}$, thus higher temperature accelerated decrystallization reaction, but the constant at $70{ }^{\circ} \mathrm{C}$ was lower than that of $50{ }^{\circ} \mathrm{C}$, indicating that acid hydrolysis was strong at the high temperature of $70{ }^{\circ} \mathrm{C}$. In this paper, the kinetic equations were obtained by ignoring acid hydrolysis, therefore the kinetic equation at $70{ }^{\circ} \mathrm{C}$ was not well fitted. Based on the above observations, the temperature of $50{ }^{\circ} \mathrm{C}$ was deemed an optimal 
condition for cellulose dissolution in phosphoric acid. The apparent activation energies (Table 5) were calculated with the following Arrhenius equation [33]:

$$
k=A_{0} e^{-E_{a} / R T}
$$

Table 5. Kinetics and Arrhenius parameters for the decrystallization of MCC with phosphoric acid.

\begin{tabular}{cccc}
\hline Parameters & $\mathbf{3 0}^{\circ} \mathbf{C}$ & $\mathbf{5 0}^{\circ} \mathbf{C}$ & $\mathbf{7 0}^{\circ} \mathbf{C}$ \\
\hline$K h^{-1}$ & 0.06 & 0.17 & 0.12 \\
$A_{0} \mathrm{~h}^{-1}$ & & $1.2 \times 10^{6}$ & \\
$E a / \mathrm{KJ} \cdot \mathrm{mol}^{-1}$ & & 42.4 & \\
\hline
\end{tabular}

The activation energy of microcrystalline cellulose dissolving in phosphoric acid (83\%) was $42.4 \mathrm{~kJ} / \mathrm{mol}$. Haisong Qi et al. [34] reported that the activation energy of cotton linters pulp dissolving in $\mathrm{NaOH} /$ urea system was about $101 \mathrm{~kJ} / \mathrm{mol}$, which was far bigger than $E_{a}$ in this paper. This suggests that phosphoric acid possess powerful solubilization towards cellulose. By combining equations (3) and (4), we obtained a modified prediction model that could be expressed as:

$$
T t s=1-e^{-A_{0} t e^{-E_{a} / R T}}
$$

To test the reliability of Equation (5), theoretical fits to the data obtained at 30 and $50{ }^{\circ} \mathrm{C}$ were compared to experimental observations (Figure 10).

Figure 10. Experimental and mathematical transformation rate points of MCC: A (30 and $\left.50{ }^{\circ} \mathrm{C}\right), \mathrm{B}\left(70^{\circ} \mathrm{C}\right)$.
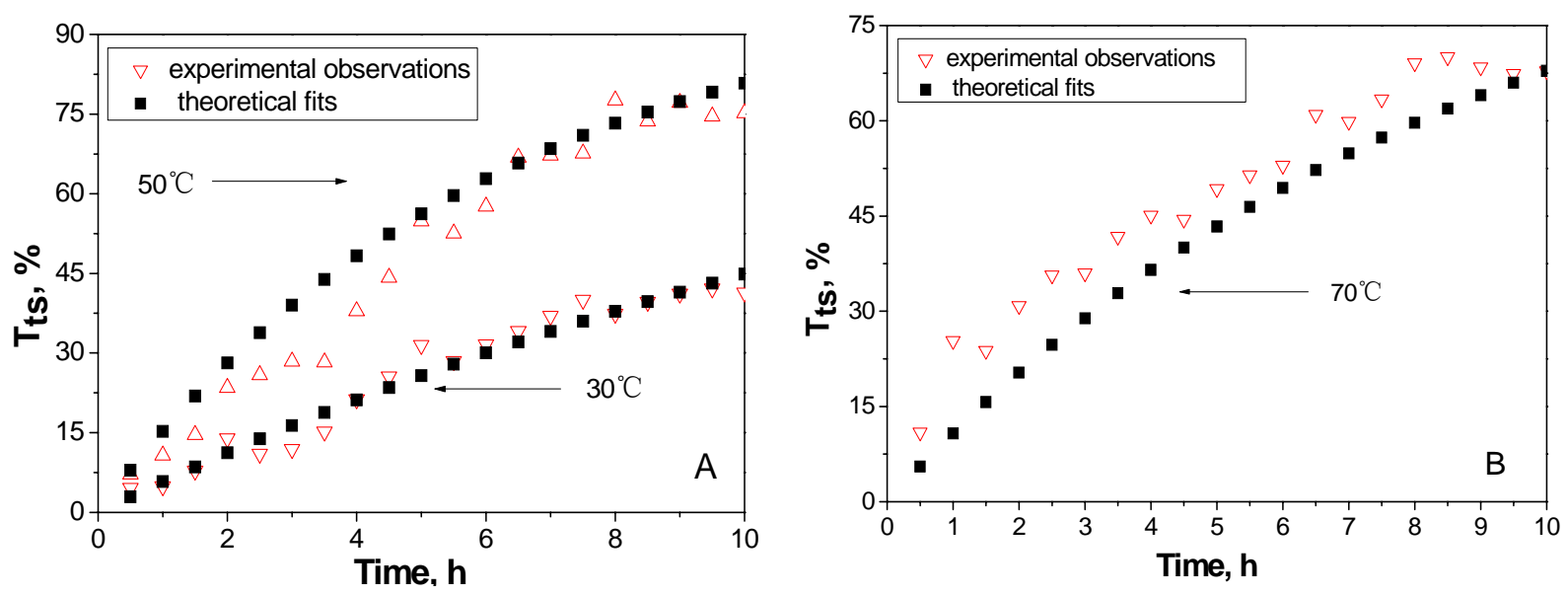

Figure $10 \mathrm{~A}$ shows the experimental and mathematical transformation rate of $\mathrm{MCC}$ at different temperatures. At the temperatures of $30{ }^{\circ} \mathrm{C}$ and $50{ }^{\circ} \mathrm{C}$, the mathematical points agreed well with the experimental points, but at $70{ }^{\circ} \mathrm{C}$ (Figure 10B), the mathematical points deviated from the experimental points at a certain extent. This proved again that too high a temperature would cause acid hydrolysis and the mass loss of cellulose. The results indicated that the time-dependent conversion rate of MCC crystalline cellulose to amorphous cellulose could be predicted at high accuracy with the kinetic parameters determined from the Arrhenius equation. 


\section{Experimental}

\subsection{Materials}

Microcrystalline Cellulose (MCC) was purchased from Shanghai Hengxin Chemical Reagent Co., Ltd. Phosphoric acid (83\%) was obtained from Guangzhou Donghong Chemical Plant (China).

\subsection{Sample preparation}

First, MCC (1.0 g) was soaked in deionized water $(1.0 \mathrm{~mL})$ in a $50 \mathrm{~mL}$ beaker. Then, phosphoric acid $(10 \mathrm{~mL}, 83 \%)$ was slowly added while agitating the beaker. The mixture was heated at 30,50 , or $70{ }^{\circ} \mathrm{C}$ for $10 \mathrm{~h}$ in a water bath, and a sample was collected each $0.5 \mathrm{~h}$. Then, deionized water $(50 \mathrm{~mL})$ was added and the mixture was agitated vigorously. Precipitates formed immediately and they were collected with centrifugation. These samples were washed sequentially with ethanol $(25 \mathrm{~mL}$, twice) and deionized water $(50 \mathrm{~mL}$, twice), then neutralized with $\mathrm{NaOH}$ at $\mathrm{pH} 7.0$, and finally dehydrated with acetone. Samples were dried at $50{ }^{\circ} \mathrm{C}$ overnight and then ground into powder. These samples were dried under vacuum with $\mathrm{P}_{2} \mathrm{O}_{5}$ desiccation in preparation for characterization.

We have not identified the degradation products during the acid hydrolysis with high temperature. The cellulose products are still white.

\subsection{X-ray diffraction method (XRD)}

XRD measurements were performed on a Rigaku powder diffractometer (Rigaku Industrial Corporation, Japan) with CuKa radiation. The tube voltage was set at $40 \mathrm{kV}$, and the current was set at $30 \mathrm{~mA}$ with a wavelength of $0.1542 \mathrm{~nm}$. The XRD diffraction patterns were taken over $2 \mathrm{~h}$ in the range of $5^{\circ}$ to $50^{\circ}$ at a scan speed of $12^{\circ} / \mathrm{min}$, the step size was $0.02^{\circ}$, and the exposure time was $10 \mathrm{~min}$. The results were treated with origin 8 to separate the peaks. The crystallinity index $\left(\chi_{c}\right)$ was calculated with the following formula $[35,36]$ :

$$
\chi_{c}=F_{C} /\left(F_{a}+F_{c}\right) \times 100 \%
$$

where, $F_{c}$ and $F_{a}$ are the area of the crystal (peak of cellulose I at $2 \theta=22.8^{\circ}$ ) and non-crystal regions (peak at $2 \theta=19.8^{\circ}$ ), respectively.

\subsection{Solid-State Cross-Polarization Magic Angle Spinning (CP/MAS) ${ }^{13} \mathrm{C}-\mathrm{NMR}$}

The solid-state CP/MAS ${ }^{13} \mathrm{C}$ NMR spectra were obtained on a Bruker DRX-400 spectrometer (Bruker BioSpin Group) with a $5 \mathrm{~mm}$ MAS BBO probe that employed both cross-polarization and magic angle spinning. Each experiment was conducted at ambient temperature $\left(20 \pm 1{ }^{\circ} \mathrm{C}\right)$. The spectrometer was operated at $100 \mathrm{MHz}$. Acquisition time was $0.034 \mathrm{~s}$, the delay time $2 \mathrm{~s}$, and the proton $90^{\circ}$ pulse time $4.85 \mathrm{~s}$. Each spectrum represents an accumulation of 5,000 scans. The results were treated with Origin 8 to separate the peaks. 


\subsection{X-ray Photoelectron Spectroscopy (XPS)}

All XPS studies were carried out using a Thermo-VG Scientific ESCALAB 250 photoelectron spectrometer (Thermo Fisher Scientific). The spectrometer was equipped with a monochromatic Al Ka $\mathrm{X}$-ray source $(\mathrm{h} v=1486.6 \mathrm{eV})$ at $500 \mathrm{~m}$ spot size of $150 \mathrm{~W}$ operating at $15 \mathrm{kV}$. All recorded peaks were corrected for electrostatic by setting the component peak of the saturated hydrocarbons in $\mathrm{C}_{1 \mathrm{~S}}$ spectrum to $284.60 \mathrm{eV}$. In all experiments, the base pressure in the analysis chamber was less than $2 \times 10^{-9}$ mbar.

\section{Conclusions}

The degree of crystallinity of cellulose treated with phosphoric acid decreased markedly. XRD analysis showed that the crystalline diffraction peaks decreased significantly. The high temperature accelerated the rate of cellulose dissolution in phosphoric acid, the side-reaction of acid hydrolysis was strong and caused a mass loss of cellulose at temperatures over $50{ }^{\circ} \mathrm{C}$. At relatively low temperatures, the kinetic behaviors of the crystalline cellulose decrease rate in phosphoric acid obeyed the kinetic equation $\ln (1 / 1-\mathrm{T} t s)$ well, with the rate constants of the decrystallization reactions at the temperatures of 30,50 , and $70{ }^{\circ} \mathrm{C}$ being $0.06,0.17$, and $0.12 \mathrm{~h}^{-1}$; the activation energy was $42.4 \mathrm{~kJ} / \mathrm{mol}$.

\section{Acknowledgements}

The authors are grateful for the financial support from the Natural Science Foundation of China (50776035, U0733001), the Foundation of Scientific Research for Universities (20070561038) and the Initiative Group Research Project (IRT0552) from the Ministry of Education of China, National High Technology Project (project 863) (2007AA05Z408), National Key R\&D Program (2007BAD34B01) and National Key Basic Research Program (2010CB732201) from the Ministry of Science and Technology of China.

\section{References}

1. Jarvis, M. Cellulose stacks up. Nature 2003, 426, 611-612.

2. Sianott, M.L. The cellobiohydrolases of Trichoderma reesei: A review of indirect and direct evidence that their function is not just glycosidic bond hydrolysis. Biochem. Soc. Trans. 1998, 26, 160-164.

3. Laser, M.; Schulman, D.; Allen, S.G.; Lichwa, J.; Antal, M.J.; Lynd, L.R. A comparision of liquid hot water and steam pretreatment of sugar cane baggage for bioconversion to ethanol. Biores. Technol. 2002, 81, 33-44.

4. Ooshima, H.; Burns, D.S.; Converse, A.O. Adsorption of cellulase from Trichoderma reesei on cellulose and lignacious residue in wood pretreated by dilute sulfuric acid with explosive decompression. Biotechnol. Bioeng. 1990, 36, 446-453.

5. Zhang, C.; Li, D.; Yu, H.; Zhang, B.; Jin, F. Purification and characterization of piceid-B-Dglucosidase from Aspergillusoryzae. Process Biochem. 2006, 42, 83-88.

6. Mawadza, C.; Hatti-Kual, R.; Zvamya, R.; Mattiasson, B. Purificaation and characterization of cellulases produced by two Bacilus strains. J. Biotechnol. 2000, 83, 177-187. 
7. Dadi, A.P.; Varanasi, S.; Schall, C.A. Enhancement of cellulose saccharification kinetics using an ionic liquid pretreatment step. Biotechnol. Bioeng. 2006, 95, 904-910.

8. Kwan, C.C.; Ghadiri, M.; Papadopoulos, D.G.; Bentham, A.C. The effects of operating conditions on the milling of microcrystalline cellulose. Chem. Eng. Technol. 2003, 26, 185-190.

9. Sun, R.C.; Mott, L.; Bolton, J. Isolation and fractional characterization of ball-milled and enzyme lignins from oil palm trunk. J. Agric. Food Chem. 1998, 46, 718-723.

10. Sun, X.F.; Sun, R.C.; Paul, F.; Baird, M.S. Extraction and characterization of original lignin and hemicelluloses from MCC. J. Agric. Food Chem. 2005, 53, 860-870.

11. Zhao, H.; Kwak, J.H.; Yong, W.; Franz, J.A.; White, J.M. Effects of crystallinity on dilute acid hydrolysis of cellulose by cellulose ball-milling study. Energy Fuels 2006, 20, 807-811.

12. Anantharam, P.D.; Sasidhar, V.; Constange, A.S. Enhancement of cellulose saccharification kinetics using an ionic liquid pretreatment step. Biotechnol. Bioeng. 2006, 95, 904-910.

13. Roseneau, T.; Potthast, A.; Sixta, H.; Kosma, P. The chemistry of side reactions and by-product formation in the system NMMO/cellulose (Lyocell process). Prog. Polym. Sci. 2001, 26, 1763-1837.

14. Tsygankova, N.G.; Grinshpan, D.D.; Koren, A.O. Mndo modeling of complex formation in N,Ndimethylacetamide-lithium chloride cellulose dissolving system. Cell. Chem. Technol. 1996, 30, 357-373.

15. Wei, S.; Kumar, V.; Banker, G.S. Phosphoric acid mediated depolymerization and decrystallization of cellulose: preparation of low crystallinity cellulose-A new pharmaceutical excipient. Int. J. Pharm. 1996, 142, 175-181.

16. Zhang, Y.H.P.; Cui, J.; Lynd, L.R.; Kuang, L.R. A transition from cellulose swelling to cellulose dissolution by o-phosphoric acid: Evidence from enzymatic hydrolysis and supramolecular structure. Biomacromolecules 2006, 7, 644-648.

17. Whitmore, R.E.; Atalla, R.H. Factors influencing the regeneration of cellulose I from phosphoric acid. Int. Biol. Macromol. 1985, 7, 182.

18. Zhang, Y.H.P.; Ding, S.Y.; Mielenz, J.R.; Cui, J.B.; Elander, R.T.; Laser, M.; Himmel, M.E.; McMillan, J.R.; Lynd, L.R. Fractionating recalcitrant lignocellulose at modest reaction conditions. Biotechnol. Bioen. 2007, 97, 214-223.

19. Mosier, N.; Wyman, C.; Dalem B. Features of promising technologies for pretreatment of lignocellulosic biomass. Bioresour. Technol. 2005, 96, 673-686.

20. Walseth, C.S. Occurrence of Cellulases in enzyme preparations from microorganisms. Tappi 1952, 35, 228-233.

21. Zhang, Y.H.P.; Lynd, L.R. Determination of the number average degree of polymerization of cellodextrins and cellulose with application to enzymatic hydrolysis. Biomacromolecules 2005, 6 , $1510-1515$.

22. Ekenstam, A. Fractional solution of rayon pulp in phosphoric acid; a new method for studying the polymerization. Svensk Papperstidn. 1942, 45, 61.

23. Danilove, S.N.; Gintse, N.F. The role of phosphoric acid in the study and treatment of cellulose. I swelling and solution of cellulose in phosphoric acid. Z.h. Obsch. Khim. 1956, 26, 3014.

24. Teeäär, R.; Lippmaa, E. Solid state carbon-13 NMR of cellulose: Relaxation study. Polym. Bull. 1984, 12, 315-318. 
25. Kono, H.; Yunoki, S.; Shikano, T.; Fujiwara, M.; Erata, T.; Takai, M. CP/MAS ${ }^{13} \mathrm{C}$ NMR study of cellulose and cellulose derivatives. 1. Complete assignment of the CP/MAS ${ }^{13} \mathrm{C}$ NMR spectrum of the native cellulose. J. Am. Chem. Soc. 2002, 124, 7506-7511.

26. Bardet, M.; Emsley L.; Vincendon, M. Two-dimensional spin-exchange solid-state NMR studies of ${ }^{13}$ C-enriched wood. Solid State Nucl. Magn. Reson. 1997, 8, 25-32.

27. Morjanoff, P.J.; Gray, P.P. Optimization of steam explosion as a method for increasing susceptibility of sugarcane bagasse to enzymatic saccharification. Biotechnol. Bioeng. 1987, 29, 733-741.

28. Galas, E.P; Romanowskia, Y.R. Hydrolysis and transformation of cellulose with aspergillus niger IBT-90 enzymes. Acta Biotechnol. 1997, 17, 339-349.

29. Larsson, P.T.; Wickholm, K.; Iversen, T.A. CP/MAS ${ }^{13} \mathrm{C}$ NMR investigation of molecular ordering in celluloses. Carbohyd. Res. 1997, 302, 19-25.

30. Focher, B.; Palma, M.T.; Canetti, M.; Torri, G.; Cosentino, C.; Gastaldi, G. Structural differences between non-wood plant celluloses: Evidence from solid NMR, vibrational spectroscopy and Xray diffractometry. Ind. Crops Prod. 2001, 13, 193-208.

31. Heux, L.; Dinand, E.; Vignon, M.R. Structural aspects in ultrathin cellulose microfibrils followed by ${ }^{13}$ C CP-MAS NMR. Carbohyd. Polym. 1999, 40, 115-124.

32. Dorris, G.M.; Gray, D.G. The surface analysis of paper and wood fibres by ESCA. II. Surface composition of mechanical pulps. Cell. Chem. Technol. 1978, 12, 721-734.

33. Eken-Saracoglu, N.; Mutlu, S.F.; Dilmac, G.; Cavusoglu, H. A comparative kinetic study of acidic hemicellulose hydrolysis in corn cob and sunflower seed hull. Biores. Technol. 1998, 65, 29-33.

34. Qi, H.S.; Chang, C.Y.; Zhang, L.N. Effects of temperature and molecular weight on dissolution of cellulose in $\mathrm{NaOH} /$ urea aqueous solution. Cellulose 2008, 15, 779-787.

35. Zhou, D.; Zhang, L.N.; Guo, S.L. Mechanisms of lead biosorption on cellulose/chitin beads. Water Res. 2005, 39, 3755-3762.

36. Focher, B.; Palma, M.; Canetti, T.; Torri, M.; Cosentino, G.C.; Gastaldi, G. Structural differences between non-wood plant celluloses: Evidence from solid state NMR, vibrational spectroscopy and X-ray diffractometry. Ind. Crops Products 2001, 13, 193-208.

Sample Availability: Samples of the compounds are available from the authors.

(C) 2009 by the authors; licensee Molecular Diversity Preservation International, Basel, Switzerland. This article is an open-access article distributed under the terms and conditions of the Creative Commons Attribution license (http://creativecommons.org/licenses/by/3.0/). 